\title{
APONTAMENTOS SOBRE A IMAGEM DA VILANIA: uma leitura do horário nobre ${ }^{1}$
}

\author{
Notes on the villain image: a reading of the prime time schedule
}

\author{
Rosita Hummell \\ Celina Alvetti
}

\section{Resumo}

A imagem da vilania - uma leitura do horário nobre tem como objetivo levantar aspectos da imagem do vilão, na representação da dramaturgia brasileira de televisão. Para isso, examina as novelas Senhora do destino e Páginas da vida, veiculadas pela TV Globo. A análise é complementada com o resultado de um grupo de discussão, feito com acadêmicos de Jornalismo e Publicidade da PUCPR, que participam de projeto do qual este artigo é parte.

Palavras-chave: Imagem; Vilania; Telenovela.

\section{Abstract}

The objective is to study aspects of the villain image on Brazilian TV dramas. Two soap operas, Lady of Destiny and Pages of Life, both broadcasted by Globo TV, were analyzed. The analysis is complemented with the results of a focus group, in which students of Journalism and Publicity of PUCPR took part, as well as they participate to the project that originated this article.

Keywords: Image; Villain; Soap opera.

1 Uma versão do presente trabalho foi apresentada na VI Bienal Ibero-americana de Comunicação, em setembro de 2007, em Córdoba, Argentina.

2 Rosita Hummell - Socióloga, Mestre em História, leciona na graduação e na pós-graduação da PUCPR, nas áreas de sociologia da comunicação e metodologia científica. Curitiba - PR. e-mail: rosita.loyola@pucpr.br

3 Celina Alvetti - Jornalista, Mestre em Artes, professora das áreas de cinema e teorias da comunicação, na graduação e na pós-graduação da PUCPR. Curitiba - PR. e-mail: celina.alvetti@gmail.com 


\section{Introdução}

No Brasil, a perspectiva histórica da televisão permite observar a forma pela qual os meios de comunicação perpassam as relações sociais; sua trajetória evidencia o modo como permearam estas relações nas últimas décadas, apresentando ressonâncias no cotidiano social. Integrada à rotina da maior parte dos brasileiros, discute temas de interesse público e, ao mesmo tempo, também determina assuntos para serem discutidos. No horário nobre, na telenovela, em particular, o que move a ficção são as tensões reais (BUCCI, 1996) vividas pelo receptor.

Por outro lado, atualmente, o imaginário social é construído com o suporte da imagem midiática. Assim, a noção de um imaginário socialmente construído, tendo a televisão um papel relevante especialmente nas sociedades urbanas desde o final do século XX , permite entender, no cotidiano brasileiro, o papel do meio e de seu principal produto, a telenovela, consolidada como o que mais vai ao encontro dos anseios de consumo de uma média dos espectadores.

Mesmo sendo um produto cultural produzido de forma empresarial, com intuitos e formas organizacionais, a novela trabalha com elementos que tratam da vida afetiva, amorosa e familiar. Não se trata de uma descrição detalhada $\mathrm{da}$ realidade, mas de uma forma social e culturalmente estabelecida de interpretar esta realidade. Inserida no ritmo do cotidiano, ela faz comentários acerca de uma sociedade em processo de transformação, permitindo uma justaposição de concepções sociais nem sempre coerentes e tampouco complementares. É evidente, então, que a novela pode ter uma atuação social constituindo um texto cultural capaz de promover emoções, afetos, sofrimentos. Em exemplos de interação com a novela, os espectadores entram em contato com situações e sentimentos, refletem e discutem sobre suas vidas privadas. Entre os produtos que se oferecem para consumo estão modelos de estilo de vida preparados para habituar o espectador, criando necessidades e satisfações.

O lugar que a novela brasileira ocupa, no entanto, foi consolidado com o tempo - ao longo dos últimos 55 anos, mais exatamente. A primeira produção foi da TV Tupi de São Paulo - Sua vida me pertence, de Walther Forster, feita ao vivo, com 20 capítulos veiculados, duas vezes por semana, às oito da noite, do final de 1951 até o início do ano seguinte. Desde os anos 1960, exibida diariamente, a telenovela brasileira teria sua ruptura para o moderno em 1968, com Beto Rockefeller, de Bráulio Pedroso. De acordo com Martin-Barbero; Rey (2001, p. 120), o que " sem romper de todo o esquema melodramático, irá incorporar um realismo que possibilita a 'cotidianização da narrativa' e o encontro do gênero com a história e com algumas matrizes culturais do Brasil".

Nos anos seguintes, e com a participação crescente da Rede Globo, a telenovela amadurece um perfil notadamente nacional, adotando temas mais próximos do cotidiano de um cidadão comum de qualquer classe social (mas esta realidade, devese lembrar, é sempre pautada a partir de um padrão estabelecido pela própria indústria cultural). Formalmente, ao longo dos anos, evoluiria e, com as tecnologias de ponta, também esteticamente se beneficiaria. Desse modo, como produto cultural, afirmou-se desenvolvendo um modelo que colocou a TV Globo na condição de hegemonia que ocupa.

Esse lugar central, na construção de um imaginário social e cultural perpassado pela imagem trabalhada pela técnica, é o que justifica a atenção que a ela se voltam diferentes ângulos de análise da ficção seriada. $O$ estudo aqui apresentado é parte de um projeto de leitura de telenovela, que propõe avaliar, por métodos qualitativos, a imagem da vilania nas novelas da TV Globo, a partir do ano 2000, observando a forma pela qual os inimigos são trabalhados, fazendo do vilão o inimigo público número um - pelo menos durante os picos de audiência, ou seja, quando o bem e o mal se defrontam. A base teórica do projeto inclui autores como Jesus Martin-Barbero e Douglas Kellner, além de outros estudos de imagem, imaginário e mídia, especialmente os voltados à televisão e à ficção seriada.

No recorte, que ora se apresenta, enfocamse as personagens Nazaré (Renata Sorrah), de Senhora do destino (novela de Aguinaldo Silva) e Marta (Lilia Cabral), de Páginas da vida (novela de Manoel Carlos), para discutir aspectos do modo como se representa o vilão, na dramaturgia brasileira de televisão. As novelas, do horário nobre, foram veiculadas pela Rede Globo, em 2004-5 e 2006-7, respectivamente, sendo 14 a 19 de fevereiro de 2005 e 8 a 13 de janeiro de 2007 os períodos acompanhados para este trabalho. (Ver Anexo).

É pertinente esclarecer que, ainda que se entenda como um aspecto importante, em termos gerais, neste trabalho optou-se por não considerar a 
Apontamentos sobre a imagem da vilania: uma leitura do horário nobre

questão da representação do feminino, no perfil do vilão. É evidente, no entanto, que uma das mudanças de imagem da vilania, na novela das oito (termo consagrado pelo uso, para o horário nobre, porque a novela vai ao ar após as 21 horas) da TV Globo, tem relação com a concentração do papel do vilão na figura da mulher. Acredita-se que, entre os mais lembrados do público, é possível encontrar as personagens Sandra, de Torre de Babel (criada por Silvio de Abreu), Odete Roitman, de Vale Tudo e Laura, de Celebridade (ambas da dramaturgia de Gilberto Braga), vilãs com traços bem demarcados, movidas por egoísmo, vaidade, desejo de vingança, questões que o senso comum tende a associar ao feminino.

Do ponto de vista dramatúrgico, é necessário observar que se considera implícito, nesta leitura, os tratamentos pelos quais passa a personagem, ao longo da novela: a direção e seus instrumentos, como a câmera, a edição de imagem e de som, mais a composição e a performance do ator. Destes elementos, é a câmera que mais opera como um recurso externo, para apoiar intenções ou oferecer interpretações. Com uma gramática cujo tratamento, na linguagem da novela, favorece a homogeneização da recepção, é fator determinante da influência e da força narrativa.

Aponte-se ainda, não menos incidente, a trajetória do vilão, em relação à natureza da ficção seriada da televisão brasileira, que vai amoldando a personagem, ao longo do tempo de duração da novela, de acordo com a recepção do público. Como o processo de criação do autor acontece simultâneo à exibição, entende-se que alguns traços vão sendo acentuados, outros atenuados, mas que o perfil e os conflitos determinados na sinopse inicial não mudam, estruturalmente.

Feitas essas considerações, propõe-se uma análise que busca reconhecer, nas novelas, a imagem da vilania, a partir da observação da rejeição e atração, aspectos colocados no perfil da personagem e que contribui para a construção desta imagem. Considera-se a ficção seriada como um produto comunicacional, e tendo em conta o fato de que, como produto cultural, ela é submissa à lógica da mercadoria, trabalhando códigos acessíveis ao receptor médio.

Como método de análise do produto novela, recorre-se à análise da imagem em movimento, conforme Rose, adequado para orientar uma análise das representações sociais no audiovisual:
Todo passo, no processo de análise de materiais audiovisuais, envolve transladar. E cada translado envolve decisões e escolhas. Existirão sempre alternativas viáveis às escolhas concretas feitas, e o que é deixado de fora é tão importante quanto o que está presente. A escolha, dentro de um campo múltiplo, é especialmente importante quando se analisa um meio complexo onde a translação irá, normalmente, tomar a forma de simplificação. Nunca haverá uma análise que capte uma verdade única do texto. (BAUER; GASKELL, 2002, p. 343-344).

\section{O enfoque no papel do vilão}

A invocação de um inimigo tem sido tema do imaginário social desde a literatura até os jogos eletrônicos. A invocação de um inimigo comum se torna ainda mais atraente quando se resgata deste imaginário a trama que conquista a atenção, a emoção e o coração do indivíduo, partindo da disputa entre o bem e o mal; o belo e o feio; o herói e o vilão.

Como afirma Kellner (2001), a mídia não se preocupa com a identidade das audiências, assim esta relação vai tornando esta audiência múltipla e única ao mesmo tempo, pois, capaz de gravitar em torno de grande variedade de papéis, imagens e atividades sem se preocupar com modificações e transformações, ou ainda, pode-se acrescentar, sem delimitar o território de pertença de faixas etárias, classes sociais, sexo e origem.

No modelo da novela brasileira, por vezes há um afastamento do melodrama tradicional; em outras vezes, é igualmente sentimentalista, com traços caricaturais nas personagens. Estão presentes, constantemente, a questão dos laços, principalmente de sangue, os conflitos de identidade perdida e as questões de afeto, todas facilmente reconhecíveis pelo receptor.

Por outro lado, o vilão vem se atualizando. Primeiro, porque as características do melodrama, mudando, levam a um ajuste do vilão; depois, porque mudaram os conceitos de moral da sociedade, em cujo equilíbrio reside uma das funções do gênero. E, por fim, ainda que não seja comum a transgressão, é evidente que no papel do vilão já se vê algum questionamento, o que torna a figura um pouco mais de nuançada, às vezes, mais ambígua, aproximando-a da atualidade. 
Do ponto de vista temático, é fato que as questões sociais passaram a fazer parte do repertório das telenovelas brasileiras e a permear os temas cotidianos.

Schiavo (2002) explica:

Essa evolução temática se justifica por duas razões principais. Em primeiro lugar, responde a uma característica intrínseca ao merchandising social: a contemporaneidade. Para ser efetivo em seus propósitos de alavancar e sustentar mudanças comportamentais junto aos telespectadores, o merchandising social deverá estar em conexão direta com as expectativas gerais da sociedade. Além disso, sua efetividade também depende da aceitação da telenovela pela audiência. Sendo a telenovela um produto de edutainment dirigido a grandes audiências, as expectativas do público telespectador também devem ser levadas em consideração. Isso implica elaborar cenas e/ou situações socioeducativas mais próximas ao cotidiano dos telespectadores, fundadas nas questões sociais que mais o preocupam, no momento. A Rede Globo e os autores de telenovelas e/ou minisséries, por sua vez, também vêm contribuindo para essa evolução ao abordar, com freqüência, temáticas modernas em suas produções.

\section{Aspectos da vilania em senbora do destino e páginas da vida}

Senhora do destino conta a história de Maria do Carmo que sai, ainda jovem, com os filhos, do interior de Pernambuco e chega ao Rio de Janeiro em um dia de caos, em dezembro de 1968, quando é decretado o Ato Institucional número 5. A única pessoa que a ajuda é Nazaré, justamente quem seqüestra seu bebê, para fazê-la de sua filha e, assim, comprometer o homem que se torna seu marido, depois de abandonar a mulher por causa do bebê que Nazaré diz ser dele. Quando ele descobre a mentira, é morto por Nazaré. Trinta anos mais tarde, Maria do Carmo está rica e continua à procura da filha raptada. Nazaré, que criara o bebê e mais uma enteada, vê esta investigar a morte do pai e, desse modo, desencadear a solução do conflito principal, o desaparecimento da criança.

A vilã, Nazaré, veio do Nordeste para o Rio de Janeiro, ascendendo socialmente por conta do casamento. Com o seqüestro, é colocada em oposição à heroína desde o início e sua trajetória passa a ser pontuada por situações que não consegue controlar, gerando outros crimes e desequilíbrio emocional, em cenas que vão do cômico ao patético. A personagem é mostrada como infantil, mas sedutora, que utiliza o sexo para se beneficiar, entendendo que isso é, em alguns períodos, parte da sua profissão. Demonstra ambição, vendo o dinheiro como fator indispensável para ter poder; lida com a afetividade do mesmo modo, por exemplo, em relação às filhas que cria (ela é estéril), no caso, a enteada e a seqüestrada.

Os aspectos de rejeição que evidencia têm relação com questões éticas e morais, a começar pela imagem de sedução, mostrada como algo perverso. Ainda que estereotipada, a personagem tem clara aproximação à realidade, no sentido de evocar Vilma Martins, que esteve na mídia por conta do seqüestro de crianças que disse ter dado à luz, depois de raptálas (em 1979 e em 1986), do mesmo modo que Nazaré. O caso real mobilizou a opinião pública e foi, possivelmente, um dos fatores de rejeição do público à personagem da novela. Evidentemente, existe também uma sedução que o vilão exerce, por conta da catarse que provoca. Sintomaticamente, a purgação acontece especialmente quando a personagem é surrada, como se a violência cristalizasse o desejo de justiça do espectador.

É pertinente observar o modo como a violência física é encarada nas novelas, como justificativa para punição do vilão. A agressividade reprimida, na vida, pelas regras de civilidade, encontra na ficção um escape. Chega a parecer natural, então, a agressão que Marta, vilã de Páginas da vida, leva do marido (depois de morder a mão dele, disputando um cheque), até então aparentemente submisso à violência verbal da mulher. Em termos de trajetória, parece ser aí que esta vilã começa a ser derrotada. No início da novela, Marta batera na filha, expulsando-a de casa, ao vê-la grávida. Depois que o marido a pune, ela ainda reverte a situação, mas passa a ter alucinações com a filha morta e desejo de matar a neta, com medo de ser descoberta.

Essa manifestação de sintomas de loucura em Marta começa decorridos cerca de 150 capítulos. Aí, já se passou mais da metade da novela, que se inicia quando Fernanda, grávida de gêmeos, é abandonada pelo namorado, volta ao Brasil e morre ao dar a luz, sob os cuidados da médica Helena. Esta adota um dos bebês, portador da Síndrome de 
Apontamentos sobre a imagem da vilania: uma leitura do horário nobre

Down, rejeitado pela avó, Marta, que diz a todos que a criança morreu. Cinco anos mais tarde, o pai se aproxima da família de Marta e passa a disputar a guarda dos filhos. É quando começam a vir à tona as mentiras da vilã, movida por ambição e sentimentos egoístas.

Ainda que o argumento da novela Páginas da Vida seja bastante fragmentado (como o título sugere, são recortes do cotidiano de diversas personagens, de várias famílias), a estrutura narrativa, mesmo aparentemente mais complexa, deixa evidente o papel de Marta como oposição à própria filha, Fernanda, ao contrariar a sua vontade de ter os filhos sendo criados juntos. Assim, a questão central, das crianças, é freqüentemente deslocada para outros temas e a carga emocional acentuada pelos conflitos dos diferentes núcleos.

Com essa questão, fica exposto o dilema da vilã, que concentra ao mesmo tempo a angústia em relação às suas atitudes como mãe e a necessidade de afirmação individual, para ela relacionada a status. De origem classe média, Marta quer ascender socialmente. É isso, provavelmente, o que a leva a investir no estudo da filha, no exterior, o que potencializa a sua decepção quando a filha não faz o que a mãe idealizou. E o que desencadeia dar a neta para adoção e, simbolicamente, ceder o neto ao pai por um cheque.

Com o objetivo de complementar a análise da vilania na novela Páginas da vida, que se encerrou no início de 2007, foi realizada uma segunda etapa do trabalho com uma discussão com o grupo de alunos do Núcleo Imagem em Movimento da PUCPR. Esses alunos cursam Comunicação Social e participam de análises fílmicas e teóricas desenvolvidas no Núcleo, em reuniões semanais. ${ }^{4}$ Portanto, os alunos assistem regularmente às novelas e já possuem experiência em análises do gênero.

As considerações colocadas durante a discussão permitiram que se confirmassem algumas considerações já colocadas na primeira etapa do trabalho: a questão proposta de que a vilania se adapta às mudanças sociais e, no caso da novela, de ser construída com realidades distintas; a trama é sempre imaginária, dramática e de certa forma estereotipada, mas os temas são atuais, cotidianos e de grande repercussão pública.
Da discussão foi possível resgatar:

- reconhecimento da tendência em colocar a vilã (no caso das duas novelas comparadas) como personagens com qualidades e defeitos perfeitamente normais, ou seja, possíveis de serem encontradas nas relações interacionais e não só no imaginário; neste caso, com mais evidência a Marta de Páginas da vida que a Nazaré de Senhora do destino.

Assim, a vilã seria má, mas nem tanto (conforme o grupo de discussão); teria atitudes desculpáveis ou até compreensíveis; no caso de Marta, principalmente. Um ponto importante foi a comparação das atitudes de Marta, com as atitudes das mães dos alunos (segundo os próprios alunos), não as atitudes de Nazaré. Sendo assim, seria possível compreender o comportamento da primeira porque fruto da criação repressiva da geração desta (e das mães).

As atitudes não desculpáveis de Marta ficariam por conta dos extremos das decisões: rejeitar uma criança com Síndrome de Down seria normal e bumano; processo de aceitação não seria fácil nem mesmo imediato; a vilania estaria, portanto, na atitude de abandonar a criança.

Segundo as observações, o marido dela, ao contrário do que poderia se pensar, foi rotulado como um indivíduo inseguro, não trabalhador e pouco consistente e que de certa forma justificaria a posição tomada pela vilã, pois teria que arcar sozinha com os custos de uma criança que exigiria maiores cuidados. A atitude sonhadora da filha Nanda também foi avaliada como pouco realista e assim a da mãe Marta, até justificável, nos mesmos limites das atitudes não extremadas.

Segundo o grupo, a vilã tradicional foi Sandra (Daniele Winits) que sempre despertou ódios e agiu como verdadeira destruidora de tramas amorosas e que, portanto, (mesmo em uma história lateral) foi devidamente castigada, vendo o sonho de um casamento mágico ser arrebatado pela irmã.

Se comparada à vilania de Nazaré, a de Marta seria menos odiosa; e como se questionava no início deste trabalho, a vilania não se configura mais pessoal, emocional e vingativa e sim em posições de convivência social consideradas pouco inclusivas e que, na atualidade, fazem parte de comportamentos socialmente não sancionados de intolerância das diferenças e da inclusão social.

\footnotetext{
4 Bruno Gabriel; Débora Rapoport Coifman; Felipe Buquera; Flávia Zanforlim; Gilson Garret Algauer Júnior; Lorena Brustolin Iplinski; Paula Silveira de Vasconcelos Fiúza; Tiago Veiga Valdivieso.
} 
A grande questão levantada na discussão foi, no entanto, sobre o aborto; segundo o grupo de discussão, este tema foi várias vezes levantado sem, no entanto, ser discutido ou avaliado, foi de certa forma banalizado. O desfecho da novela conseguiu atrelar a manutenção da gravidez como tomada de decisão dos mocinhos da novela e as decisões (mesmo no passado) de interromper a gravidez estão associados a personagens que ocupavam o lado perverso da trama.

Os alunos classificaram, portanto, a novela como uma possibilidade de questionar, avaliar e incentivar o espectador a tornar parte da discussão de questões polêmicas; apontaram, no entanto, (especialmente com relação à novela mais recente) a superexposição de temas sociais e a validade de depoimentos reais; observou-se a necessidade de manter limites entre o real e o imaginário.

A inserção de temas sociais e atuais, segundo o grupo, deve ser pontual e não constante; a superexposição levaria o espectador a perder, de certa forma, o interesse pela narrativa.

Cita-se Durand, à guisa de conclusão deste

estudo:

A enorme produção obsessiva de imagens encontra-se delimitada ao campo do 'distrair'. Todavia, as difusoras de imagens - digamos a 'mídia' - encontram-se onipresentes em todos os níveis de representação e da psique do homem ocidental ou ocidentalizado. A imagem mediática está presente desde o berço até o túmulo, ditando as intenções de produtores anônimos ou ocultos; no despertar pedagógico da criança, nas escolhas econômicas e profissionais do adolescente, nas escolhas tipológicas (a aparência) de cada pessoa, até nos usos e costumes públicos ou privados, às vezes como 'informação', às vezes velando a ideologia de uma 'propaganda' e noutras escondendo-se atrás de uma 'publicidade' sedutora.... ( DURAND, 2001, p. 33-34).

\section{Considerações finais}

A partir das características da imagem do vilão das novelas, a se considerar as personagens propostas, Nazaré e Marta, em Senhora do destino e Páginas da vida, respectivamente, é possível fazer algumas constatações, à guisa de conclusão.
Considerando a perspectiva da polarização dos anseios do grupo no que diz respeito à criação pela mídia de inimigos comuns, externos ao contexto social, mas que unificam os interesses e a rejeição e que promova, de certa forma a coesão do grupo contra um inimigo, mesmo imaginário, tanto Nazaré como Marta se encaixam no perfil do vilão desejado.

Do ponto de vista dramatúrgico, as personagens analisadas têm uma função bem evidente, no enredo. Marta apresenta mais ambiguidade do que Nazareth. Ainda que esta não esteja construída de modo plano, tem mais definidas as características tradicionais de vilania e o mal está presente na sua natureza. Já Marta parece mais carregar o amargor da frustração, exteriorizando isso. De qualquer forma, ambas são posicionadas de modo claro, quanto à sua função para, de modo homogêneo em relação à recepção, provocar o seu reconhecimento como inimigo público.

A Marta de Páginas da vida, ao contrário da Nazaré de Senhora do destino, não tem um perfil colado ao de uma figura da realidade, mas provoca identificação porque tem como fator de atração poder ser igual a qualquer mãe brasileira. De certa maneira, Marta é uma personagem mais atualizada, mais realista. A rejeição que provoca é bem evidente, pois é mostrada sem remorso, por exemplo, imaginando matar a neta, para que o seu universo não se desestruture. Ao mesmo tempo, é ambígua quando se emociona ao assistir Casablanca na televisão de plasma, objeto de desejo concretizado com o dinheiro do pai de seus netos.

Constata-se que os vilões da novela são apresentados de modo sedutor, mas o maniqueísmo ainda é predominante, talvez em função do veículo. Como, tradicionalmente, o vilão é o antagonista do herói, mesmo que não tenha confrontos de porte apenas com ele. Mas, mais que contraponto ao protagonista, esse vilão serve à novela para pôr em pauta os temas que tendem a provocar discussões éticas e morais, em geral desencadeadas pela luta do bem contra o mal, que ele representa.

Por mais que o vilão seja, em determinadas fases da novela, colocado em uma condição de provocar empatia, é mesmo o sentimento de rejeição que predomina. Mais que isso, de certa maneira ele tem uma função catártica. Por isso, não é possível afirmar que exista uma inovação da imagem do vilão, ainda que a sua forma seja revestida de aspectos 
renovadores, do ponto de vista formal (não é mais predominantemente feio e com cara de mau) e do ponto de vista ético - são freqüentemente ambíguos.

Mas a força de oposição, na novela, não se dá só com os vilões ou pela presença de antiheróis, como categorias intermediárias. Ela comporta personagens secundários com aspectos do mal, de defeitos de caráter a fraquezas emocionais. É o caso, em Senhora do destino, um político corrupto e de um homem, que explora as mulheres com quem vive. Em Páginas da vida, um mosaico do cotidiano, defeitos de conduta são repartidos entre vários personagens - entre eles um pai alcoólatra, um marido mulherengo, a irmã de caridade, intransigente, a adolescente preconceituosa. Parece que assim, sintomaticamente, no país da televisão, reconhece-se o país real.

\section{Referências}

BAUER, M.; GASKELL, G. Pesquisa qualitativa com texto, imagem e som: um manual prático. Petrópolis: Vozes, 2002.

BUCCI, Eugênio. Brasil em tempo de TV. São Paulo: Boitempo, 1996.

DURAND, Gilbert. O imaginário: ensaio acerca das ciências e da filosofia da imagem. Rio de Janeiro: Difel, 2001.

KELLNER, D. A cultura da mídia. Bauru: EDUSC, 2001.

MARTIN-BARBERO, Jesus; REY, German. Os exercícios do ver. São Paulo: SENAC, 2001.

SCHIAVO, Marcio Ruiz. Merchandising social nas telenovelas e a construção da cidadania. Reposcom, 2002. Disponível em:<www.intercom.org.br $>$. Acesso em: 25 abr. 2007.

\section{Anexos}

Ficha técnica: Páginas da Vida

Formato/Gênero: novela

Duração: 50 min. aprox.

Criado por: Manoel Carlos

Elenco: Regina Duarte; Lilia Cabral; Marcos Caruso; Tarcísio Meira; e grande elenco.

Rede: Rede Globo de Televisão.

Transmissão original: 10 de julho de 2006 - 2 de março de 2007.

Número de episódios: 203

Direção: Jaime Monjardim.

\section{Ficha Técnica: Senhora do Destino}

Formato/Gênero: novela.

Duração: 50 min. aprox.

Criado por: Aguinaldo Silva

Elenco: Suzana Vieira; Renata Sorrah; José Wilker; Glória Menezes; Raul Cortez; Carolina Dieckman e grande elenco.

Número de episódios: 221

Rede: Rede Globo de Televisão.

Transmissão original: 28 de junho de $2004-12$ de março de 2005.

Direção: Wolf Maia. 